1st International Conference - Global Ethics - Key of Sustainability (GEKoS) | May 15th, 2020 | Bucharest, Romania

\title{
Ethical Context of Entrepreneurship in the Swine Breeding Sector of Romania
}

\author{
Cristinel Gigi SONEA, Andra Cristina SONEA, \\ Alina Iuliana TABIRCA \\ https://doi.org/10.18662/lumproc/gekos2020/23
}

How to cite: Sonea, C.G., Sonea, A.C., Tabirca, A.I. (2020). Ethical Context of Entrepreneurship in the Swine Breeding Sector of Romania. In A. Grigorescu \& V. Radu (vol. ed.), Lumen Proceedings: Vol. 11. 1st International Conference Global Ethics - Key of Sustainability (GEKoS) (pp. 223-235). Iasi, Romania: LUMEN Publishing House.

https://doi.org/10.18662/lumproc/gekos2020/23 


\title{
Ethical Context of Entrepreneurship in the Swine Breeding Sector of Romania
}

\author{
Cristinel Gigi SONEA ${ }^{1, *}$, Andra Cristina SONEA ${ }^{2}$, \\ Alina Iuliana TABIRCA ${ }^{3}$
}

\begin{abstract}
This paper is of particular importance in the development of a business, taking into accountthe ethical issues arising from the livestock sector, with a focus on the pig sector, for Romanian agriculture. Following an analysis carried out in the Romanian pig sector, it was concluded thatthe share of pig breeding had been decreased as regards the intensive farming, and 70\% of them were found in rural households, particularly vulnerable in economic crisis conditions. Pork consumption has increased due to largely pork imports, which contributes to a negative trade balance in this sector. However, for 2015-2019 period, the production of live pigs and pig meat is expected to increase, due to increased financial support, by creating new modern farms applying the latest breeding technologies, ensuring a complete biosecurity system 'from farm to fork', having access to structural funds and also respecting the EU quality standards.
\end{abstract}

Keywords: Swine; business; pigmeat sector; market analysis; pig breeding.

\footnotetext{
${ }^{1}$ Valahia University of Targoviste, Romania, cristinel.sonea@yahoo.com

2 IDSA Bucharest, Romania, andracristina.sonea@gmail.com

31 Decembrie 1918 Alba Iulia University, Romania, alina tabirca@yahoo.com

* Corresponding author.

(C) The Authors, LUMEN Conference Center \& LUMEN Proceedings.

Selection and peer-review under responsibility of the Organizing Committee of the conference
} 


\section{Introduction}

In a context of continuous development of the human society, the population explosion and the increase of nutritional requirements, lead to the objective need for development and modernization of the animal production. To ensure food needs, the main source of development of this sector is the workforce, and mainly specialists in various sectors such as veterinarians, animal breeders, agronomists, economists, scientists in animal husbandry, etc. The most important question as regards the fight against world poverty and hunger is the provision of animal protein for maintaining health, vitality and the well-being of the human race[3]. The pig herds represent the main weapon in the fight against poverty and pig farming represents the forefront and an essential source of animal protein supply. The biological and economic characteristics, as well as the quality of the pig meat, have led to a general interest as regards pig breeding in almost all countries of the world [15]. Raising pigs due to their biological characteristics has a number of economic and social benefits.

Pigs have a high proportion of meat in the carcass that ensures high efficiency in relation to consumption. This proportion varies from country to country, andthe average pig meat consumption is over $40 \%$. In Romania, pig meat represents a main category in consumer's preferences, covering over $50 \%$ of total meat consumption. Meat is the main production in pig breeding, and it has an important role for human food consumption and the provision of necessary key elements, namely: proteins, fats, vitamins, minerals[22]. The pig is a specialized animal and appreciated for its meat, but atthe same time, it is a laboratory animal, a recognized model that is being used for various scientific research in the field of nutrition, genetics, reproduction, behaviour, surgery, in the drug industry and organ transfer[7]. Large-scale production processes are constantthroughoutthe year, and incomes are particularly important for farmers in order to develop this sector.

\section{Literature Review of Swine Breeding Sector}

Animal husbandry is an important branch of agriculture, which aims to breed, reproduce, and improve farm animals [2]. The breeding and improvement of animal breeds are necessary for providing the population with good quality animal products, by developing the food and light industry and ensuring the necessary raw materials for these industries [17]. Livestock plays a key role in capitalizing the plant production and transforming it into 
animal products[20],[23]. Also, plant production ensures a whole range of fodder necessary for animal feeding and determines an increase inthe economic efficiency in agriculture[8]. Romania is obliged to promote multifunctional animal husbandry in the next period, which ensures the development of the rural environment. Thus, animal breeding musttake into accountthe following elements:

- maintaining the tradition;

- maintaining the rural characteristic;

- maintenance of activities in rural communities;

- maintaining the population in rural areas, especially young people;

- environmental protection.

The growth and development of this sector represents a viable business for farmers, with an important role in the development of the national economy, by creating new jobs, but also providing the raw materials needed for the food and light industry and the management of natural factors (water, soil, air, biodiversity etc.) and a particularly important role in the sustainable development of rural areas [9],[16].

The social effects as regards the development of pig farms culminate in providing employment in rural areas [24]. Since ancienttimes, swine rearing in our country has been an important matter for the population, especially for those in rural areas. For the beginning, predominated an extensive increase in primitive pig populations, based on the Stocli and Mangalita breeds, as well as other local populations [4]. Atthe end of the past century and the beginning of the present century, more improved breeds were imported), especially from England, Denmark, both for breeding and for the improvement of existing populations[10]. This activity has always been a source of food and raw material for farmers to meet family needs, but also for trade. Pig farming, under the conditions of our country, is a very important economic branch, which is characterized by the intensive production, starting with the production of piglets and ending with the continuous, rhythmic and constant delivery of individuals fattened for slaughter[18],[18].Among the zootechnical branches, pig rearing ranks second place after cattle. The main product obtained from pigs is meat, which is requested and appreciated by the consumers due to: its nourishing value, succulence, and tenderness, the ease to prepare in a rich assortment of dishes, the possibility of preservation in different forms and over a long period of time[1],[13]. By its higher protein and fat content, its energy value (expressed in $\mathrm{Kcal} / \mathrm{kg}$ ) is higher than in other species: - $2700 \mathrm{Kcal}$. for pork; - 1600 Kcal. According to F.A.O., O.M.S. as well as some Romanian 
specialists' recommendations, a "standard" person should daily receive between 2800-3000 kcal and about $1 \mathrm{~g}$ protein for each $\mathrm{kg}$ weight, for which about $73 \mathrm{~kg}$ of meatis needed annually (in carcass), of which: $-13.3 \mathrm{~kg}$ of beef, $-5.1 \mathrm{~kg}$ of sheep meat, $-27.9 \mathrm{~kg}$ of pig meat, $-15.9 \mathrm{~kg}$ of poultry meat $-10.5 \mathrm{~kg}$ of other resources (mainly fish meat), plus about $240 \mathrm{~kg}$ of milk and milk products and 280 eggs.

In the ethical context of the business intended for breeding and processing pigs, Romania represents an agro-industrial country with a very high agricultural potential that could ensure the food needs for over 80 million people, compared to some European countries and with the capacity to develop this sector and to become a major producer of biological material and exporter[6],[15]. That is why it is necessary that from an ethical point of view to improve the development of the sector.

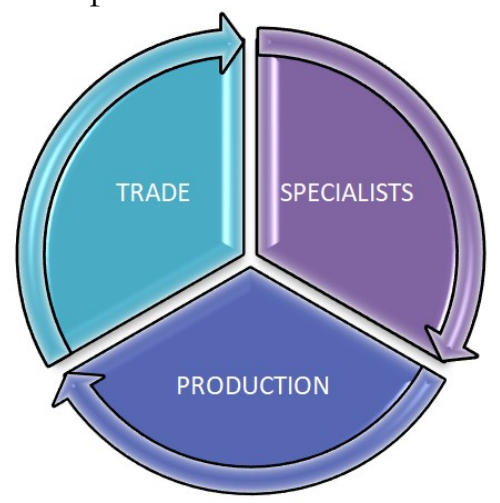

Graphic 1. Diagram of ethical actions in the pig breeding business Source: authors interpretation

To understand the specifics of the swine sector, the link between business and ethics is treated from a supply chain perspective, to understand how ethical issues can be pursued in the analysis of the supply chain with pigmeat products and how which food processes assess the potential effects on the supply chain[5]. In our view the sector is in need of well-trained staff covering various fields of development such as skilled workers, zootechnical technicians, zootechnical engineers specialized in the fields of breeding, reproduction, nutrition, etc., that will take into account of the bouse, feed \& breed triad. An important role in ensuring and maintaining animal health as well as food safety is played by veterinarians and veterinary technicians. Going further on the technological flow, the food industry benefits from a well-trained human resource. As it can be observed, each field from an ethical point of view has a diversity of well-trained specialists on the technological chain[12],[26]. 
The national support granted for pig farmers and pig meat production over the last years is provided as follows:

- By Law no. 195/2018 financial support is granted to pig breeders who carry out both setting up new farms and breeding activities. The purpose of this program is to create over 100,000 new accommodation places in breeding farms, which will result in obtaining a minimum number of 2,500,000 piglets for fattening. This will ensure the necessary number of piglets for fattening in Romania with a total value of 359.1 million euro, by respecting the EU standards as regards the breeding activity. The improved breeds will record an increase in growth clearly superior to the local breeds by reaching the slaughter weight, between $90-110$ $\mathrm{kg}$, at 6 months.

- Another measure to supports farmers is the Animal Welfare Measure regulated by Regulation (EU) no. 1307/2013, which allows farmers who voluntarily undertake to carry out operations consisting of several commitments in favor of animal welfare and are also active farmers. The commitments are referring to maintenance conditions such as lighting, ventilation, watering, etc., covered by payments that are assuring the additional costs and the loss of income generated by the implementation of these commitments. These commitments are voluntary, are aimed to favour pig's welfare, and are concluded for a period of 1 year.

- Another aid that the breeders receive is the de minimis aid and represents the number of piglets received free of charge from the Bazna and/or Mangalita breeds, the beneficiaries being the breeders. The development period of the de minimis scheme is 2018 - 2020, and the aid is 250 lei/head for piglet suppliers, and the total amount for 2019 was 4.6 million lei.

- National or International minimus schemeis another support granted for pig breeders and represents the number of piglets received free of charge from the Bazna and/or Mangalita breeds. The development period of the de minimis scheme is 2018 2020, and the aid consists of 250 lei/head for piglet suppliers. The total ceiling for this scheme in 2019 was 4.6 million lei.

The analysis of the development scenarios of the complexes for the swine sector, in the conditions of economic integration with the use of different management approaches, showed that without state regulations, the national enterprises of this complex will not be able to survive the external competition[21]. 


\section{Research Study}

The total number of pigs decreased in the 2015-2018 period, reaching in 2018 the lowest number, respectively 3925 thousand heads, due to the evolution of African Swine Fever in our country, given that about 400,000 pigs were killed. Also, regarding the total number of pigs in the first 11 months of 2019 compared to the same period of 2018, they decreased by 57 thousand heads, respectively, by $1.4 \%$. At the same time, the number of sows registered in 2018, a decrease of $11.7 \%$, compared to 2017 , when the number of queen sows was 350 thousand heads. Pig meat production in December 2019 compared to the same period of 2018 decreased by 46 thousand tons, respectively, by $7.6 \%$. The lowest pig meat production was registered in 2018 (around 551 thousand tons), and compared to the 2016 production, a downward trend can be observed, which represents $6.29 \%$.

The total pig meat imports experienced an upward trend, in 2018, reaching 332.938 tons, compared to 2015 , when the imports were 221.410 tons. Regarding the total export of pig meat, it decreased in 2018 compared to 2017 by 13.943 tons, respectively, by $42.27 \%$.

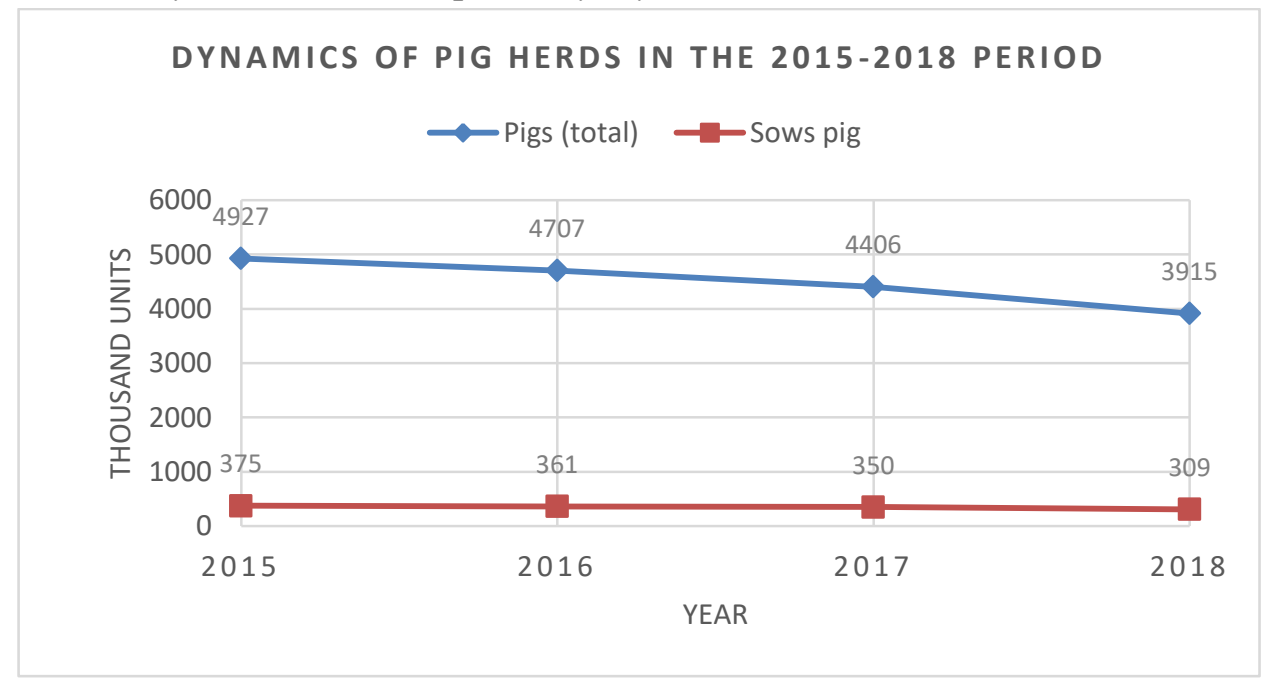

Graphic 2. Dynamics of pig herds in the 2015-2018 period

Source: Romania National Institute of Statistics

From the graph above, a downward trend of the herds can be observed in 2018, reaching the smallest level of this period, respectively 3.925 thousand heads. This is the result of the African Swine Fever evolution in our country, given that about 400.000 pigs were killed. 
Cristinel Gigi SONEA et al. | Lumen Proceedings 11 | GEKoS2020

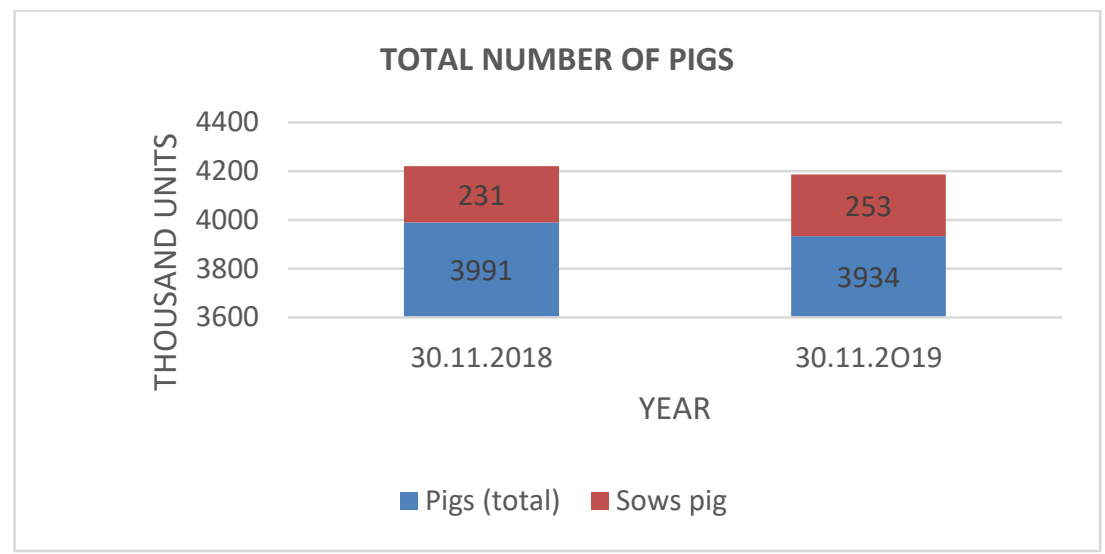

Graphic 3. Total number of pigs, out of which sows (30.11.2018 - 30.11.2019) Source: MARD operative data

At the same time, the number of sows decreased by $11.7 \%$ in 2019 compared to the number of sows in 2018. Pig meat production decreased in 2019 by 46 thousand tons, respectively, by $7.6 \%$, compared to the same period of 2018.

Regarding the pig meat production, the lowest level was registered in 2018 (around 551 thousand tons), and compared to the 2016 production (588 thousand tons), a downward trend of $6.39 \%$ can be observed.

\section{DYNAMICS OF OF LIVE PIGMEAT PRODUCTION IN THE 2015-2018 PERIOD}

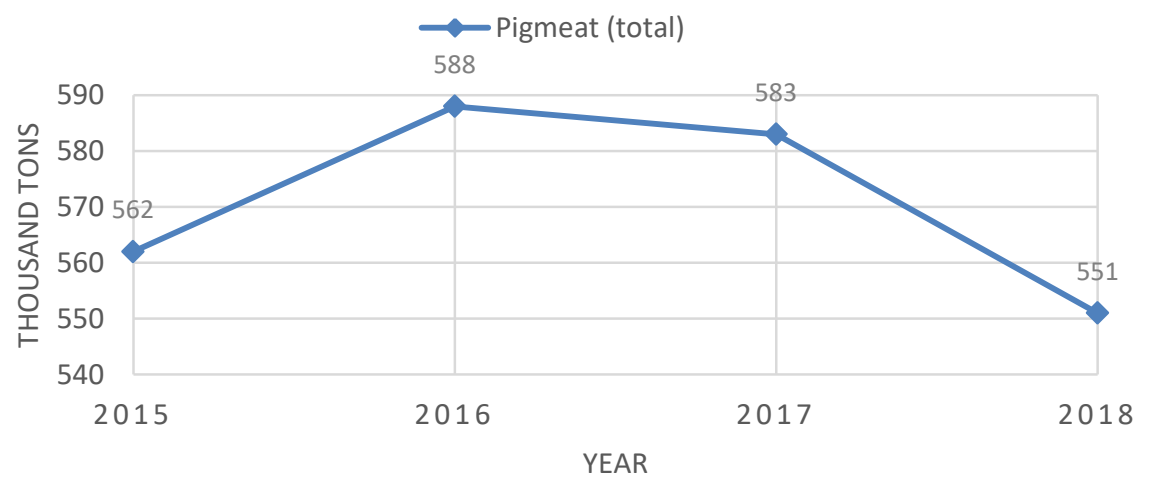

Graphic 4. Dynamics of live pigmeat production between 2015 - 2018 Source: Romania National Institute of Statistics

The total pig meat imports experienced an upward trend in 2018, reaching 332.938 tons, compared to 2015, when the imports totalized 221.410 tons. 


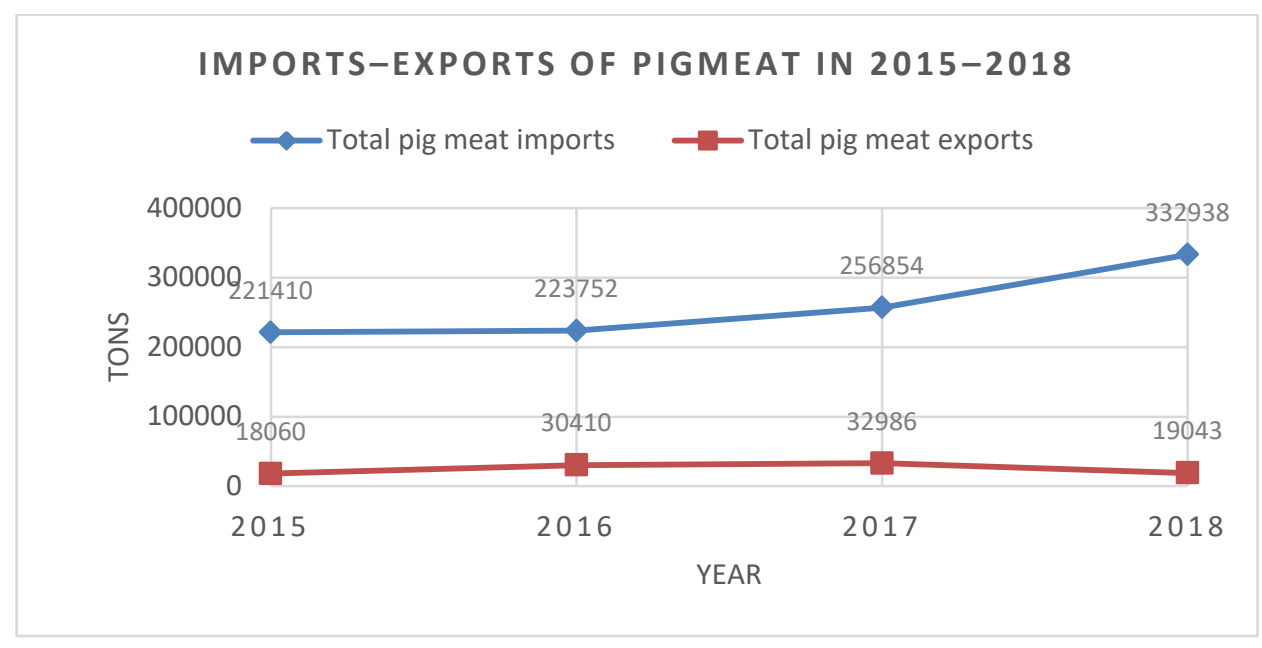

Graphic 5. Imports - Exports of pigmeat in 2015 - 2018

Source: Romania National Institute of Statistics

As regards the total export of pig meat, it decreased in 2018 compared to 2017, by 13943 tons, respectively by $42.27 \%$.

In 2015 pig meat consumption was $31.7 \mathrm{~kg} /$ capita and increased by 2018 to $36.9 \mathrm{~kg} /$ capita, respectively $16.4 \%$, resulting in an increased import of pig meat. In 2018 the pig meat price was around $1.675 € / \mathrm{kg}$ for the live pig meat and $1.893 € / \mathrm{kg}$ for the refrigerated \& frozen meat.

Regarding the meat quality, the pig meat produced in Romanian farms has a very good quality, taste, and meat preselling particularities, due to good quality feed. The quality of the feed was proven by the average daily increase of $750 \mathrm{grams} / \mathrm{head}$; the animals reached in $90-110 \mathrm{~kg}$ in $165-170$ days. At the same time, the average daily consumption of combined feed, in order to obtain one $\mathrm{kg}$ of weight gain, was $3.1 \mathrm{~kg}$ for the fattening pigs, ensuring a carcass with over $56 \%$ muscle tissue and a layer of fat under 15 $\mathrm{mm}$, as well as special taste qualities. The fattening for bacon production is done in order to obtain carcasses with a thin layer of bacon, where the pigs are grown to reach up to $70-80 \mathrm{~kg}$. The combined feed recipe used in order to feed pigs for bacon must contain a percentage of crude protein higher than $1-2 \%$ in previous recipes and a lower content of metabolizable energy in order not to favours fat deposits.

The quality of Mangalita pig meat is very good due to the percentage of unsaturated fatty acids in this meat that reaches $70 \%$, which is a similar percentage to the one found in olive oil or salmon, which according to researchers is very suitable for those suffering from cardiovascular diseases. Due to the fact that it is a rustic breed and is not very pretentious to the feeding and housing conditions, a good disease resilience, a prolificacy of 6-7 
piglets, specific consumption of 5.5 -6 kilograms of food and the average daily increase of 400 grams. From the beginning of the weaning to the slaughterhouses to the slaughterhouses and after taking into account the phrase from the farm in the fork, the biosecurity and traceability elements of the pork are followed in such a way that at the time of exposure for sale, the meat meets the veterinary sanitary conditions.

From fattening till slaughter, the phrase from the farm in the fork is taken into account, by following the biosecurity and traceability elements, so that at the time sale the meat complies with the veterinary sanitary requirements.

\section{Findings}

Consists in processing and interpreting statistical data by which we observe the growth trend of this sector from year to year, a fact proven by the increased pig meat consumption per capita and by taking into account the fact that Romania is a large meat consumer, especially pig meat.

However, during the analysed period, there was a decrease due to the "Swine Fever" epidemic, which led to the decimation of herds in the outbreak areas, while seeking to limit it[14]. Also, this epidemic had negative economic effects at the national level through the decrease of herds, production, and consumption, which conducted to a decrease in meat export and led to a negative trade balance[25].Research on consumer attitudes and preferences for pigmeat products is very imperceptible. Consumers'attitude towards pigmeat products is mainly influenced by quality attributes. Ethical factors are important in somecases, but they can be overestimated[11].As a result of these elements described above, the state came up with additional measures aimed to support the pig farming sector, by setting up and developing breeding farms, so that small farmers have the possibility to buy piglets for fattening produced in Romania. An important role in the development of this sector is also represented by the support granted to local breeders of Mangalita and Bazna breeds, as a gene reserve.

The results of the literature analysis led to the identification of support strategies for business development in the pig sector:

- Objectives of the pig breeding sector:

- Increasing the number of farms and the herd of pigs can only be achieved by setting up breeding farms and test centers in order to reach the upper level of breeding, namely the breeding pyramid. 
- The low efficiency of pig prices is due to the fact that Romania after the 1990s gave up large breeding farms, and became tributary to imports of piglets for fattening from large international companies.

- Improving the genetic value of sows with the aim to increase total meat production and quality can be achieved by involving a lot of money in livestock research and obtaining good quality piglets from improved breeds clearly superior to local ones.

- Improving production performance by adopting breeding technologies can be achieved by using the latest technologies designed to obtain superior results in the shortest possible time.

- The conservation of the gene pool for the breeds exposed to the risk of extinction can be achieved by two methods of conservation in situ and ex-situ.

- Support measures necessary for the pig breeding sector:

- Financial incentives granted, at the same level and under the same conditions, to EU livestock breeders applying the same Common Agricultural Policy rules.

- Supporting the improvement of animal populations by providing financial support to animal breeders and breeders' associations, in accordance with the principles of the EU, for the improvement of the quality of breeds but also for the maintenance of genealogical data through accredited associations.

- Increasing the expansion of reproductive biotechnology, especially artificial insemination, embryo transfer. Funding from the national budget the establishment of breeding laboratories, using the best specialists.

- Encouraging the development of the breeding industry so as to ensure the needs of piglets for meat production intended for the domestic consumption and by setting up breeding companies that intend to create high-quality biological hybrids.

- Supporting the purchase of high-quality biological material designed to achieve high-quality performance compared to local breeds.

- Establishing a support fund for the genetic conservation and conservation of endangered pig breeds for their maintenance of a genetic reservoir.

- Support the modernization of farms and of the manure disposal system with a view to respecting animal welfare and environmental protection. EU pig meat is governed by 
Regulation (EU) no. 1308/2013 of the European Parliament and of the Council of Dec 17, 2013 establishing a common organization of the markets in agricultural products and repealing Council Regulations (EEC) No 922/72, (EEC) No 234/79, (EC) No 1037/2001 and (EC) No 1234/2007

Agricultural ethics was conceived as an interdisciplinary subdiscipline that should now become a significant basis for analysing the norms and values implicitly assumed by researchers, practitioners and decision-makers in agriculture that assess ethical and social values equal to the economic concerns of productionand consumption.

\section{Conclusions}

The pig meat trade has low technical performance compared to the other EU member states due to low productivity in many establishments. While large producers have access to superior genetic material and highquality feed.

Even if the large breeders have access to high-quality genetic material, the fodder used in pig feeding is not managed properly. The feed has poor quality, which is not ensuring all the nutritional parameters necessary to ensure a complete and balanced recipe. Another particularly important issue at the national level is represented by the storage of green waste. Thus, biosecurity practices should be improved to avoid risk diseases.

It can be concluded that the developed innovative approach of strategic management of sustainable development should be used only for the management of the agro-industrial complex and only under the conditions of economic integration, which is its limitation.

Proposals aimed to improve the pig meat sector:

- Ensuring the production of pig meat necessary to cover national consumption and, therefore, ensuring a favourable trade balance for Romania.

- Aligning the Romanian products to the EU quality standards.

- Creating incentives to attract investment in the pig farming area and the use of structural funds.

- Increasing the relative share of animal production in the economic and social value of agricultural production.

- In the current context, the ethical component consists of ensuring staff with professional quality in such a way that obtaining results is influenced by the higher scientific level of specialists in the field, respectively ensuring a continuous flow of specialists throughout the production chain. 
Several documents and policies address the role of ethics, including issues related to health, quality, trust, environmental welfare in influencing consumer behaviour.

\section{Acknowledgement}

This work is supported by project POCU 125040, entitled "Development of the tertiary university education to support the economic growth PROGRESSIO", co-financed by the European Social Fund under the Human Capital Operational Program 2014-2020

\section{References}

[1] Alecu Ioan Niculae Management agricol. Bucharest: Editura Ceres; 2016.

[2] Bogdan AT, Mantea AS, Bogdan D (coord). Tratat de reproductie si insamantari artificiale la suine. Bucharest: Agricultural Technical Press; 1999.

[3] Bogdan AT, Oprean C, Oprean L. Managementul integrat si strategic al combaterii inteligente a crizei alimentare globale, bazat pe bioeconomie si ecoeconomie. Bucharest: Romanian Academy Press; 2012.

[4] Brown R. Lester Lumea pe marginea prapastiei, Editura: Tehnica; 2011.

[5] Conto F, Fiore M, Dicecca R. Ethics approach in food choices along the agrifood supply chain: a survey in Apulia region. In Know your food: Food ethics and innovation. Wageningen Academic Publishers. 2015: 495-503. Available from: https://doi.org/10.3920/978-90-8686-813-1_59

[6] Croitoru G, Duica M, Robescu O, Radu V, Oprisan O. Entrepreneurial Resilience, Factor of Influence on the Function of Entrepreneur, Proceedings RCE. Iasi: Lumen Publishing House. 2017:193-216. doi:10.18662/lumproc.rce2017.1.17

[7] Dima IC, Radu V, Grabara JK, Modrak V, Bunaciu M. Logistics model for industrial waste treatment processes. Recent Researches in Environment, Energy Planning and Pollution. WSEAS Proceeding paper. 2011: 121. Available from: http://www.wseas.us/e-library/conferences/2011/Iasi/WEPRE/WEPRE20.pdf

[8] Dinu I, Cuc A, Băcilă V, Bereș M. Suinicultură. Tratat de cresterea a suinelor. Bucharest: Coral Sanivet Publishing House; 2002.

[9] Dinulescu GL, Robescu VO, Radu F, Croitoru G, Radu V. Best practices: a bioeconomic solution for replacing chemical fertilizers by organic processes for atmospheric nitrogen fixation in soil. Amfiteatru Economic, 2008; 20(48):510520. Available from: http://dx.doi.org/10.24818/EA /2018/48/510

[10] Dodor A. Exploring marketing mix for building a Viable Agro Business. British Journal of Education, Society and Behavioural Science. 2015; 6(2):78-86. Available from: http://www.journalrepository.org/media/journals /BJESBS 21/2014/Dec/Dodor622014BJESBS14877 1.pdf 
[11] Driouech N, El Bilali H, Berjan S, Radovic M, Despotovic A. Exploring the Serbian consumer attitude towards agro-food products with ethical values: organic, fair-trade and typical/traditional products. In5th International Scientific Conference "Rural Development 2011" 2011 Nov 24, Vol. 5: 37-43.

[12] Dulja X, Driouech N, Kapaj-Mane A, Nikolla M. Albanian Consumer's Behavior toward ethical values of Agro-Food Products: a Socio-Economic Analyses. Agrofor. 2016;1(1).

[13] Dumitrescu C, Marcu V, Popescu G, Moisa S, Gherman R. Ethics aspects in agrotourism. Lucrări Stiintifice Management Agricol. 2013; 15(4):311.

[14] Grigorescu A, Lincaru C, Pîrciog S, Chitescu RI. Competitiveness and sustainable development in public services. Management \& Marketing. Challenges for the Knowledge Society. 2019; 14(1):108-29

[15] Grigorescu A. Quality and customer satisfaction in public services. Amfiteatru Econ. 2008; Special Issue: 130. Available at: https://www.amfiteatrueconomic.ro/temp/Article_52.pdf

[16] Ionita-Predescu L, Radu F, Tabirca AI. Needs of local sustainable development. Annals of Faculty of Economics. 2011; 1(2):91-7. Available at: http://steconomiceuoradea.ro/anale/volume/2011/n2 /011.pdf

[17] Iordan M, Chilian MN, Grigorescu A. Regional Resilience in Romania-Between Realism and Aspirations. Procedia Economics and Finance. 2015; 22:627-35.

[18] Istudor N, Manole V, Năstase M. Compatibilizarea organizatiilor economice de profil agroalimentar cu cerintele sanitare, sanitar-veterinare şi de mediu. Bucharest: ASE Publishing House; 2008, 20-45

[19] Istudor N, Sonea C, Petrescu IE. The Perspectives of Pig's Breeding sector from Romania. Quality-access to success. 2009; 10(106):40

[20] Jones MT, Millar CC. About global leadership and global ethics, and a possible moral compass: An introduction to the special issue. Journal of business ethics. 2010 Jun 1;93(1):1-8.

[21] Ovchinnikov A, Kozenko ZN, Bichkov M, Kabanov V, Karpova A. Strategic management of sustainable development of agro-industrial complex with economic integration.European Research Studies, 2015; 11(3):307

[22] Ricci C, Marinelli N, Puliti L. The consumer as citizen: the role of ethics for a sustainable consumption. Agriculture and agricultural science procedia. 2016; 8:395-401.

[23] Richards C, Lawrence G, Burch D. Supermarkets and agro-industrial foods: The strategic manufacturing of consumer trust. Food, Culture \& Society. 2011;14(1):29-47.

[24] Sonea C, et al. Importanta agribusiness-ului în combaterea insecuritătii alimentare la nivel rural. Buzau: International Conference. Proceeding paper: 2008: 169-172

[25] Stegaroiu I, et al. Systemic Approaches to Strategic Management. Business Science ,IGI Global, 2014:Chapter 11 [ISBN 978-1-4666-6481-4]

[26] Ubrežiová I, Moravčíková K. How to perceive the corporate social responsibility in the agro-food companies? Serbian Journal of Management. 2017; 12(2):201-15. 